\title{
Hemodynamic Complications During Laser Surgery of the Larynx
}

\author{
Marinov Ts.', M. Belitova', T. Popov², N. Nizamova², J. Rangachev², D. Popova² \\ 'Department of Anesthesiology and Intensive Care; University Hospital "Queen Giovanna"- ISUL; Medical \\ University-Sofia \\ ${ }^{2}$ Department of ENT Surgery; University Hospital „Queen Giovanna"- ISUL; Medical University-Sofia
}

\begin{abstract}
:
Introduction: Laser surgery of the larynx offers several advantages over conventional surgical methods, including a bloodless operative field and microscopic precision. However, the anesthetist faces special issues in the management of these patients. The Aim of the study is to determine the hemodynamic complications during laser surgery of the larynx. Materials and Methods: A 2-year prospective cohort study of 50 patients who underwent laser microsurgery of the larynx in the Department of ENT Surgery; University Hospital „Queen Giovanna"- ISUL; Medical University-Sofia. We used total IV anesthesia. All patients were monitored and recorded for: Peripheral Capillary Oxygen Saturation $\left(\mathrm{SpO}_{2}\right)$; Systolic blood pressure (SBP), Diastolic blood pressure (DBP); heart rate (HR); continuous electrocardiography (ECG). Results and discussion: The mean age of the patients is 61.04 years. $8 \%$ of them are females and $92 \%$ are males. According to anesthesia risk assessment $4 \%$ of the patients are with ASA 1 class, $30 \%$ of them are with ASA 2 class, $64 \%$ are with ASA 3 class and $2 \%$ are with ASA 4 class. The mean duration of operation is 57.06 minutes. Mean systolic blood pressure of the patients is $141.22 \mathrm{mmHg}$, mean diastolic blood pressure is $86.2 \mathrm{mmHg}$ and mean pulse rate is 60.94 beats per minute. $44 \%$ of the patients have arterial hypertension I grade, $24 \%$ of them are with isolated arterial hypertension and $32 \%$ are with normal blood pressure. $44 \%$ of the patients had pulse rate between $45-60$ beats per minute during putting on the tube of Kleinsasser, $32 \%$ of them had pulse rate $>60$ beats per minute during putting on the tube of Kleinsasser and $28 \%$ had pulse rate $<45$ beats per minute during putting on the tube of Kleinsasser. Conclusion: Laser surgery of the larynx is specific kind of surgery which is characterized by hypertensive hemodynamic. There is a risk of severe bradycardia after putting on the tube of Kleinsasser which can cause hemodynamic instability and even cardiac arrest if not corrected immediately.
\end{abstract}

Key words: Laser surgery, hypertensive hemodynamic, bradycardia

\section{Introduction}

Laser surgery of the larynx offers several advantages over conventional surgical methods, including a bloodless operative field and microscopic precision $^{1}$. However, the anesthetist faces special issues in the management of these patients. Some of these issues are the preoperative evaluation of the degree of airway obstruction, possible behavior of the laryngeal mass with respect to airway obstruction and bleeding tendency during the operation, cooperation with the surgeon in the shared field, airway fire protocol, reduction of the inhalational hazards due to plume and eye protection against direct traumatic effects of laser beam ${ }^{2,3,4}$. One of major concerns in laryngeal laser surgery is the risk of airway fire. While airway fire is relatively uncommon, it is very serious and can result in severe morbidities and even mortality. The introduction of wrapped tubes, metal tubes, and jet ventilation techniques using a needle or metal tube have reduced the fire hazard; however, each method has its own set of problems. When endotracheal intubation is intended, its flammability is a great concern. There are few studies addressing the safety of polyvinylchloride (PVC) tubes for laser surgery. They are mainly designed in a mechanical laboratory model and have suggested conflicting results ${ }^{5,6}$. 
To conduct a safe anesthesia method for laryngeal laser surgery, the anesthetist should be familiar with the application of small-sized laser-safe tubes $^{5,6,7}$, tubeless techniques, jet ventilation ${ }^{8,9}$, and apneic methods ${ }^{10}$. When endotracheal intubation is intended, the fuel for airway fire is present (The endotracheal tube becomes a ready source of fuel if ignited by a laser). Precautions to reduce the risk of ETT ignition include the distal placement of ETT cuff, maintenance of less than $40 \%$ oxygen concentration, application of wet gauze in the surgical field, filling the ETT cuff with water instead of air, and careful attention to the laser reflections. The application of powerful smoke suction improves the visibility of surgical field and reduces the risk of displaced laser irradiation. Other safety measures, such as water syringe for rescue treatment, should also be available. Total intravenous anesthesia is the recommended method for maintenance of anesthesia. To reduce the risk of airway fire, the applied power of carbon dioxide $\left(\mathrm{CO}_{2}\right)$ laser should be limited to 2-3 $\mathrm{W}$ for benign lesions preferably with super-pulse mode. In the case of ablative surgeries, specifically in cancer patients, $8 \mathrm{~W}$ continuous mode laser is routinely used. Laser safe tubes, including wrapped tubes and metal tubes, are much more expensive than conventional PVC tubes. Moreover, metal tubes (e.g., stainless steel ETTs) have more external diameters with comparable lumen size, which impairs the exposure of laryngeal pathology. Their nearly rigid firmness makes them hardly to move and intraoperative surgical maneuvers difficult.

Anyone who has been involved with providing anesthesia for laryngeal laser surgery cannot help but be impressed by the hypertensive, tachycardic response to laryngoscopy which continues as long as the laryngoscope is in place ${ }^{11}$. The inevitable increase in myocardial oxygen consumption which accompanies this response has been shown to produce signs of myocardial ischemia under anesthesia in those patients with evidence of ischemic heart disease ${ }^{12}$. These circulatory changes must somehow be modified to prevent ischemia from occurring.

\section{Materials and Methods}

We obtain approval from local ethical review board and informed consent from all study participants. A 2-year prospective cohort study of 50 patients who underwent laser microsurgery of the larynx in the Department of ENT Surgery; University Hospital "Queen Giovanna"- ISUL; Medical UniversitySofia. We used total IV anesthesia: in all patients we used methylprednisolone $2 \mathrm{mg}$. $\mathrm{kg}-1$ for premedication. For induction in general anesthesia we used propofol $2.5 \mathrm{mg} . \mathrm{kg}-1$ and succinylcholine $1 \mathrm{mg} \cdot \mathrm{kg}-1$ as muscle relaxant. Endotracheal intubation was performed by laser safe wrapped endotracheal tube №6.5 from the anesthesiologist and mechanical ventilation was performed. For maintenance of general anesthesia we used propofol 200 to $400 \mu \mathrm{g} \cdot \mathrm{kg}-1 \cdot \mathrm{min}-1$ infusion and fentanyl $7-10 \mu \mathrm{g} . \mathrm{kg}-1$. for pain relief. Inspiratory concentration of oxygen was $25 \%$.

All patients were monitored and recorded for: Peripheral Capillary Oxygen Saturation $\left(\mathrm{SpO}_{2}\right)$; Systolic blood pressure (SBP), Diastolic blood pressure (DBP); heart rate (HR); continuous electrocardiography (ECG). The above parameters were recorded and analyzed at predetermined time intervals: 5 -th minute before intubation, every 5 minutes after intubation and 5-th minute after extubation. Descriptive statistical analysis of the results was performed.

European Society of Hypertension (ESH) and the European Society of Cardiology (ESC) classification for arterial hypertension ${ }^{19}$ (fig. 1):

\begin{tabular}{|l|c|c|c|}
\hline Category & Systolic blood pressure & & Diastolic blood pressure \\
\hline OPTIMAL & $<120 \mathrm{mmHg}$ & and & $<80 \mathrm{mmHg}$ \\
\hline Normal & $120-129 \mathrm{mmHg}$ & and/or & $80-84 \mathrm{mmHg}$ \\
\hline High normal & $130-139 \mathrm{mmHg}$ & and/or & $85-89 \mathrm{mmHg}$ \\
\hline Arterial hypertension I & $140-159 \mathrm{mmHg}$ & and/or & $90-99 \mathrm{mmHg}$ \\
\hline Arterial hypertension II & $160-179 \mathrm{mmHg}$ & and/or & $100-109 \mathrm{mmHg}$ \\
\hline Arterial hypertension III & $\geq 180 \mathrm{mmHg}$ & and/or & $\geq 110 \mathrm{mmHg}$ \\
\hline Isolated systolic hypertension & $\geq 140 \mathrm{mmHg}$ & and & $<90 \mathrm{mmHg}$ \\
\hline
\end{tabular}

Fig. 1. Classification for arterial hypertension 


\section{Results}

The mean age of the patients is 61.04 years. $8 \%$ of them are females and $92 \%$ are males. According to anesthesia risk assessment $4 \%$ of the patients are with ASA 1 class, $30 \%$ of them are with ASA 2 class, 64\% are with ASA 3 class and $2 \%$ are with ASA 4 class. The mean duration of operation is 57.06 minutes.

Mean systolic blood pressure of the patients is $141.22 \mathrm{mmHg}$, mean diastolic blood pressure is $86.2 \mathrm{mmHg}$ and mean pulse rate is 60.94 beats per minute.

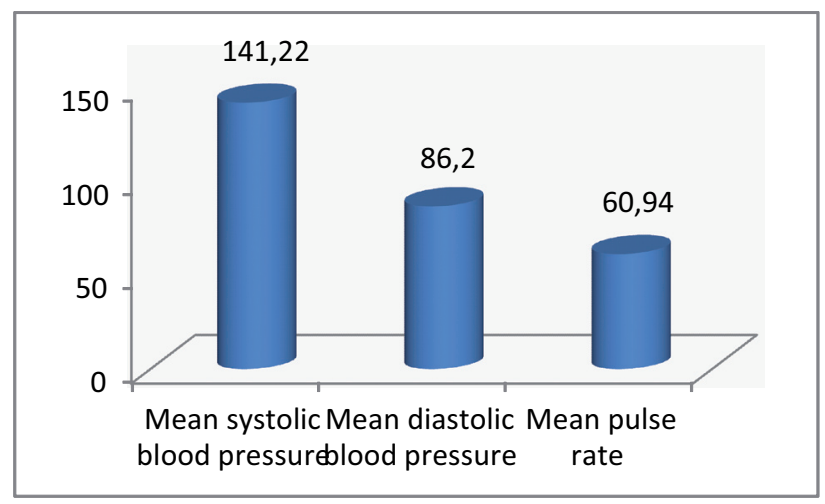

Fig. 2. Mean parameters of hemodynamic

$44 \%$ of the patients have arterial hypertension I grade, $24 \%$ of them are with isolated arterial hypertension and $32 \%$ are with normal blood pressure.

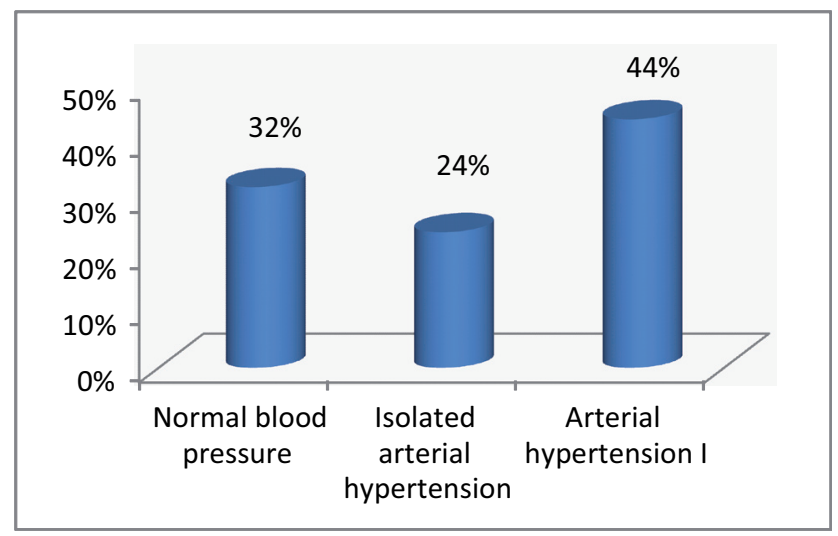

Fig. 3. Most of the patient are with hypertensive hemodynamic

$44 \%$ of the patients had pulse rate between 45 60 beats per minute during putting on the tube of Kleinsasser, $32 \%$ of them had pulse rate $>60$ beats per minute during putting on the tube of Kleinsasser and $28 \%$ had pulse rate $<45$ beats per minute during putting on the tube of Kleinsasser.

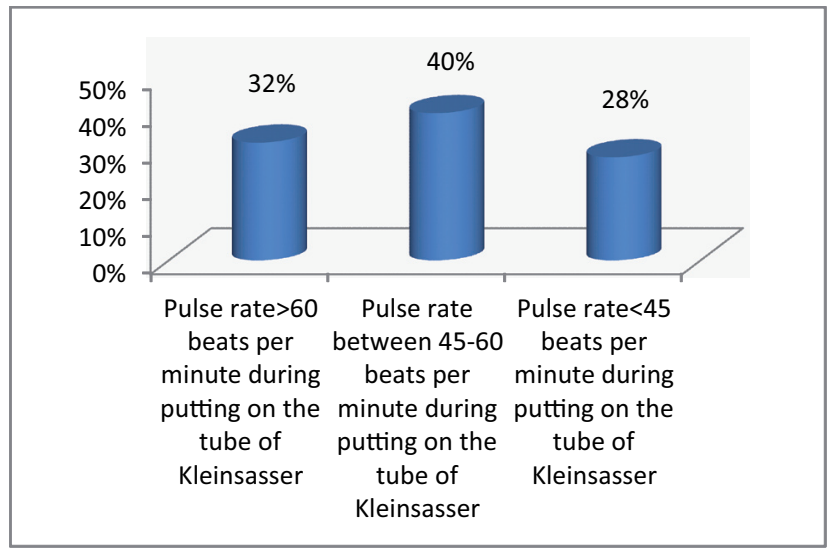

Fig. 4. Bradycardia after putting on the tube of Kleinsasser

\section{Disscusion}

Over the last 20 years, organ preservation surgery has evolved from standard external surgical approaches to resect cancer and preserve parts of the larynx to surgical procedures resecting equivalent tumors performed through an endoscope (rigid laryngoscope).

Early postoperative hemorrhage is a potentially lethal complication. Often there will be a small amount of bleeding, but significant bleeding from a major artery in the larynx can result in aspiration of blood into the airway. It is critical in this situation to secure the airway, either by endotracheal intubation or by performing a tracheostomy, followed by operative control of hemorrhage. Airway obstruction is uncommon, as resection of the tumor generally provides an airway that is more widely patent following surgery. Since the neck is not incised, there is much less postoperative swelling and edema that characterizes open surgical procedures on the larynx. However, prolonged tongue retraction and compression during long operations can result in soft tissue ischemia and in tongue edema postoperatively. Additionally, prolonged displacement of the tongue by the laryngoscope can cause temporary lingual or hypoglossal paresis. In cases lasting more than $1-2 \mathrm{~h}$, periodically releasing suspension to allow blood flow to the tongue markedly decreases the likelihood of developing postoperative tongue swelling or nerve dysfunction. The neuropathy caused by retraction is 
temporary, and generally resolves over several weeks. Also mentioned under postoperative care, aspiration can be caused by extensive resection, preexisting laryngeal impairment, advanced age or poor health. Preoperative and postoperative assessment to determine the risk for aspiration is necessary to prevent development of aspiration pneumonia. Other complications encountered include: mucosal burns of the lips, oral cavity or oropharynx, dental injuries (loosened or chipped teeth), infection, dysphagia, and airway fires or burns ${ }^{13,14,15,16,17,18}$.

In our study the mean age of the patients is 61.04 years which means that these are people in active working age. This kind of operation gives them chance to keep their ability to speak and work normally. On the other hand in this age group the risk of accompanying cardiovascular and respiratory disease is higher. In this case the risk of hemodynamic complications will be higher. Most of the patients are males $92 \%$. This may be connected with higher incidence of accompanying risk factors like smoking in male group, which is common for Bulgarian population ${ }^{20,21,22,23}$. The anesthesia risk assessment shows that most of the patients are in ASA III class 64\%. This means higher risk of accompanying cardiovascular disease and higher risk of hemodynamic complications. $44 \%$ of the patients have arterial hypertension I grade and $24 \%$ of them are with isolated arterial hypertension during operation despite of higher dosage of opioids and propofol that we used. This may be caused by the strong pain stimulus from the tube of Kleinsasser during the operation. $40 \%$ of the patients had pulse rate between $45-60$ beats per minute and $28 \%$ of them had pulse rate $<45$ beats per minute during putting on the tube of Kleinsasser. This is very dangerous reflex reaction of the heart, which we believe is caused by parasympathetic nervous system, because in some of the cases the pulse rate is corrected after administration of atropine. In other cases when the bradycardia is very severe administration of atropine cannot help so the tube of Kleinsasser must be removed, because there is a risk of cardiac arrest. After removing the tube and administration of atropine the pulse rate is normalized.

\section{Conclussion}

Laser surgery of the larynx is specific kind of surgery which is characterized by hypertensive hemodynamic. There is a risk of severe bradycardia after putting on the tube of Kleinsasser which can cause hemodynamic instability and even cardiac arrest if not corrected immediately.

\section{REFERENCES}

1. Yan Y, Olszewski AE, Hoffman MR, Zhuang P, Ford CN, Dailey SH, et al. Use of lasers in laryngeal surgery. J Voice. 2010 Jan; 24(1):102-

2. Straub HW. Protection of the human eye from laser radiation. Ann N Y Acad Sci. 1965 May 28;122:773-6.

3. Chinn SD. Complications of laser surgery: safety, risks, and the plume. Clin Podiatr Med Surg. 1992 Jul;9(3): 763-79.

4. Sheinbein DS, Loeb RG. Laser surgery and fire hazards in ear, nose, and throat surgeries. Anesthesiol Clin. 2010 Sep; 28(3):485-96.

5. Li S, Chen L, Tan F. Laryngeal surgery using a CO2 laser: is a polyvinylchloride endotracheal tube safe? Am J Otolaryngol. 2012 NovDec;33(6):714-7.

6. Roy S, Smith LP. Prevention of airway fires: testing the safety of endotracheal tubes and surgical devices in a mechanical model. Am J Otolaryngol. 2015;36(1):63-6.

7. Haas CF, Eakin RM, Konkle MA, Blank R. Endotracheal tubes: old and new. Respir Care. 2014 Jun; 59(6): 933-52; discussion 952-5.

8. Rontal E, Rontal M, Wenokur ME. Jet insufflations anesthesia for endolaryngeal laser surgery: a review of 318 consecutive cases. Laryngoscope.1985 Aug; 95(8): 990-2.

9. Hunsaker DH. Anesthesia for microlaryngeal surgery: the case for subglottic jet ventilation. Laryngoscope. 1994 Aug;104(8 Pt 2 Suppl 65):130 .

10. Werawatganon T, Supiyaphun P, Kerekhanjanarong V, Rodanant O, Sirichotewithayakorn P. Intermittent apnea and total intravenous anesthesia for microscopic laryngeal surgery.J Med Assoc Thai. 2004 May;87(5):547-50.

11. Prys-Roberts C, Greene G, Melocke R, Foesc P. Studies-of anaesthesia in relation to hypertension II: Hemodynamic consequences of induction and endotracheal intubation. Br J Anaesth, 1971; 43: 531.

12. Roy WL, Edelist G, Gilbert B. Myocardial ischaemia during non-cardiac surgical procedures in patients with coronary-artery disease. Anesthesiology, 1979; 51: 393-7.

13. Corvo MA, Inacio A, Mello MB, Eckley CA, Duprat Ade C (2007) Extra-laryngeal complications of suspension laryngoscopy. Braz J Otorhinolaryngol 73(6):727-732. 
14. Klussmann JP, Knoedgen R, Wittekindt C, Damm M, Eckel HE (2002) Complications of suspension laryngoscopy. Ann Otol Rhinol Laryngol 111(11):972-976.

15. Preuss SF, Cramer K, Klussmann JP, Eckel HE, Guntinas-Lichius O (2009) Transoral laser surgery for laryngeal cancer: outcome, complications and prognostic factors in 275 patients. Eur J Surg Oncol 35(3):235-240.

16. Rosen CA, Andrade Filho PA, Scheffel L, Buckmire R (2005) Oropharyngeal complications of suspension laryngoscopy: a prospective study. Laryngoscope 115(9):1681-1684.

17. Vilaseca-Gonzalez I, Bernal-Sprekelsen M, Blanch-Alejandro JL, Moragas-Lluis M (2003) Complications in transoral CO2 laser surgery for carcinoma of the larynx and hypopharynx. Head Neck 25(5):382-388.

18. Pearson BW, Salassa JR, Hinni ML (2005) Transoral laser micro resection of advanced laryngeal tumors. In: Cummings CW, Flint PW, Haughey BH, Robbins KT, Thomas JR, Harker LA, Richardson MA, Schuller DE (eds) Cummings otolaryngology: head and neck surgery, 4th edn. Elsevier Mosby, Philadelphia.

19. Mancia, Giuseppe, et al. „2013 Practice guidelines for the management of arterial hypertension of the European Society of Hypertension (ESH) and the European Society of Cardiology (ESC): ESH/ESC Task Force for the Management of Arterial Hypertension." Journal of hypertension 31.10 (2013): 1925-1938.

20. Маринов Ц., М. Белитова, Т. Попов, Ю. Рангачев, Д. Попова. Рискови фактори за възникване на периоперативни усложнения при пациенти, подложени на ларингектомии. ОтоРиноЛарингология международен бюлетин, XIV, 2018;3:14-18.

21. Маринов Ц., М. Белитова, Т. Попов, Д. Конов, М. Цекова-Чернополска, М. Милков. Разпространение и значимост на ларингеалния карцином. ОтоРиноЛарингология международен бюлетин, XIV, 2018;1:23-27.

22. Маринов Ц., М. Белитова, Т. Попов. Характеристика на контингента пациенти с ларингеален карцином в българската популация. Анестезиология и интензивно лечение, XLV, 2016;3:11-14.

23. Маринов Ц., М. Белитова, Т. Попов. Соматични проблеми при пациенти с карцином на ларинкса и ларингектомия. Анестезиология и интензивно лечение, XLIV, 2015;4:30-33.

\section{Correspondence to:}

Tsvetomir Marinov, MD, PhD

Department of Anesthesiology and Intensive Care

University Hospital ,Queen Giovanna”- ISUL

Byalo More Str 8

Medical University-Sofia

E-mail: ts.marinov@abv.bg

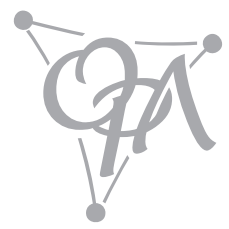

